\title{
NOTAS SOBRE MÉTODOS PARA A PESQUISA ARQUITETÔNICA PATRIMONIAL
}

\section{RESUMO}

O artigo possui como objeto de discussão a explanação de notas sobre métodos para pesquisa arquitetônica de bens com valor patrimonial, desenvolvida pela autora desde 2007 e adotados por seu grupo de investigação em projetos de iniciação científica acadêmica e em programas de pós-graduação de instituição federal brasileira. Devido às dificuldades dos estudantes seguirem um método que os oriente no desenvolvimento de trabalhos investigativos, ao longo dos anos o grupo construíu uma linha de trabalho que dialoga com autores clássicos na área de pesquisa arquitetônica, como Katinsky (2005), Serra (2006), Rovira e Gáston (2007), resultando numa proposta metodológica que tem obtido bons produtos acadêmicos como trabalhos de conclusão de curso, monografias, dissertações, artigos publicados em periódicos, anais de eventos nacionais e internacionais. Dessa forma, o objetivo do artigo é expor aos interessados; a possibilidade de mais um caminho a ser seguido por jovens pesquisadores na elaboração de análises arquitetônicas que não sejam apenas descritivas, mas também, críticas. De forma sucinta, a metodologia trabalha com sete dimensões da arquitetura, a saber: 1) Dimensão normativa; 2) Dimensão histórica; 3) Dimensão espacial (sendo 3.1 Espaço externo; 3.2 Espaço interno); 4 ) Dimensão Tectônica; 5) Dimensão Funcional; 6) Dimensão formal; 7) Dimensão da conservação do objeto. A proposta se justifica, portanto, pela necessidade de, ao se iniciarem nas investigações sobre as edificações, os jovens pesquisadores poderem dispor de uma pauta que os oriente neste percurso. Certamente, tal proposta metodológica está sujeita a revisões, procurando aperfeiçoamento e, justamente por isso, é divulgada.

PALAVRAS-CHAVE: arquitetura; projeto arquitetônico; tectônica; patrimônio arquitetônico; análise arquitetônica.

\section{RESUMEN}

El artículo posee como objeto de discusión, una explanación de pautas sobre métodos para la investigación arquitectónica de bienes con valor patrimonial, conforme desarrollada por la autora desde 2007 y adoptada en su grupo de investigación en el desarrollo de proyectos de iniciación científica académica y en programas de posgrado de instituciones del Gobierno federal brasileño. Debido a las dificultades de los estudiantes en seguirem un método que los guíe en el desarrollo de trabajos de investigación, a lo largo de los años se ha construido una línea de trabajo que dialoga con autores clásicos en el área de pesquisa arquitectónica, como Katinsky (2005), Serra (2006), Rovira y Gáston (2007), resultando en una propuesta metodológica que ha obtenido buenos productos académicos como trabajos de conclusión de cursos, monografías, disertaciones, artículos publicados en revistas, anales de eventos nacionales e internacionales. De esa manera, el objetivo del articulo es exponer a los interesados la posibilidad de más un camino a ser seguido por jóvenes investigadores, para la elaboración de análisis arquitectónicas, que no sean apenas descriptivas, pero también, críticas. La metodología funciona con siete dimensiones de la arquitectura, a saber: 1) Dimensión normativa; 2) Dimensión histórica; 3) Dimensión espacial (3.1 Espacio exterior; 3.2 Espacio interior); 4) Dimensión tectónica; 5) Dimensión funcional; 6) Dimensión formal; 7) Dimensión de la conservación del objeto. Está justificado por la necesidad de que los jóvenes investigadores comiencen a investigar edificios y tengan un guión para guiarlos en esto camino. Ciertamente, dicha propuesta metodológica está sujeita a revisiones, buscando mejoras y, por lo tanto, se divulga.

PALABRAS CLAVE: arquitectura; proyecto arquitectónico; tectónica; patrimonio arquitectónico; analisis arquitectónico.

\section{ABSTRACT}

The article has as its object of discussion, the explanation of notes on methods for architectural research of assets with patrimonial value, developed by the author since 2007 and adopted in her research group in the development of academic scientific initiation projects and graduate programs from a Brazilian federal institution. Due to the students' difficulties in following a method that guides them in the development of investigative works, over the years it has been built a investigation line that dialogues with classical authors in the area of architectural research, such as Katinsky (2005), Serra (2006), Rovira and Gáston (2007), resulting in a methodological proposal that has obtained good academic products such as course conclusion papers, monographs, dissertations, articles published in journals, annals of national and international events. Thus, the objective of the article aims to expose to those interested the possibility of another way to be followed by young researchers, for the elaboration of architectural analyzes, which are not only descriptive, but also critical. Briefly, the methodology works with seven dimensions of architecture, namely: 1) Normative dimension; 2) Historical dimension; 3) Spatial dimension (3.1 Outer space; 3.2 Internal space); 4) Tectonic dimension; 5) Functional Dimension; 6) Formal dimension; 7) Dimension of object conservation. It is justified by the need for young researchers to start investigating buildings and have an agenda to guide them in this path. Certainly, such methodological proposal will always go through revisions, seeking improvement, and therefore, it is disclosed, to be discussed.

KEYWORDS: architecture; architectural project; tectonic; architectural heritage; Architectural analysis. 


\section{INTRODUÇÃO}

O artigo possui como objeto de discussão a explanação de notas sobre métodos para pesquisa arquitetônica de bens com valor patrimonial, desenvolvida pela autora desde 2007, e adotada em seu grupo de investigação no desenvolvimento de projetos de iniciação científicos acadêmicos e em programas de pós-graduação de instituição federal brasileira.

Devido às dificuldades dos estudantes em seguirem um método que os oriente no desenvolvimento de trabalhos investigativos, ao longo dos anos foi construída uma linha de pesquisa que dialoga com outros autores clássicos na área, como Katinsky (2005), Serra (2006), Rovira e Gáston (2007), resultando numa proposta metodológica que tem obtido bons produtos acadêmicos, como trabalhos de conclusão de curso, monografias, dissertações, artigos publicados em periódicos, anais de eventos nacionais e internacionais.

Dessa forma, o objetivo do artigo é expor aos interessados na área a possibilidade de mais um caminho a ser seguido por jovens pesquisadores para a elaboração de análises arquitetônicas, que não sejam apenas descritivas, mas também, críticas, agregando informações primordiais para a apreensão e compreensão do objeto arquitetônico, e relacionando-o com seus mais distintos condicionantes.

Tais análises arquitetônicas podem estar presentes tanto em estudos de casos para o desenvolvimento de projetos arquitetônicos, como também em estudos patrimoniais de edificações de distintos períodos estilísticos, que possam sofrer (ou não) projetos de intervenção.

Não se tem a pretensão de realizar aqui um estudo teórico-filosófico sobre um método de investigação, mesmo porque autores consagrados na área da metodologia da pesquisa e, especificamente, da pesquisa arquitetônica, já se aprofundaram no tema de forma clara, como Eco (1989), Serra (2006), Katinsky (2005) e Viegas (1999). De fato, as reflexões que aqui serão tratadas resultam de uma prática acadêmica ao longo de trinta e cinco anos desenvolvendo estudos, orientações e análises arquitetônicas junto aos estudantes de arquitetura em instituições de ensino federais. Trata-se, portanto, de um caminho na análise do objeto arquitetônico após as fases da pesquisa que vão desde a coleta de dados em fontes primárias e secundárias, até a seleção de objetos arquitetônicos, os quais serão analisados e diagnosticados com fins específicos em cada caso estudado.

Sabe-se, ainda, que há muito a ajustar nesta proposta metodológica, pois o constante trabalho com novos objetos de investigação (que sempre estão surgindo) nos faz estar sempre revisando-a, acrescentando pontos de vista ou mesmo fazendo a junção de elementos a fim de aprimorá-la. No momento, estamos trabalhando para a análise do objeto arquitetônico com valor patrimonial tendo por base o uso das sete dimensões aqui listadas como as fundamentais, em sua interação com a arquitetura: a dimensão normativa, histórica, espacial, tectônica, funcional, formal e de conservação. Sabe-se que poderiam entrar mais variantes, que criassem dimensões, mas até o momento o trabalho realizado tem se limitado a estas e está funcionando bem, conforme será exposto.

\section{APORTE TEÓRICO}

O objeto arquitetônico vem a ser o foco desta metodologia, isto é, a edificação: um bem imóvel, construído, possuidor de valores culturais, históricos, arquitetônicos, construtivos, espaciais, formais, funcionais e que sofrem patologias que o transformam ao longo dos anos, atuando diretamente na dimensão de sua conservação física enquanto objeto construído.

Katinsky (2005, p.43) defendeu que o objeto da arquitetura é o estudo simultâneo da coisa e sua imagem, argumento que teve um grande peso para o embasamento desta metodologia, pois se concorda com o citado autor, quando este indica que o próprio edifício ("a coisa") é umas das principais fontes de pesquisa e consequentemente, de análise. Parte-se do princípio que o próprio edifício é uma fonte primária da pesquisa, "um documento construído" como descrito pelo professor:

Em história da arte e, principalmente, em arquitetura, são fontes primárias as próprias obras, os esboços e desenhos preparatórios, bem como, os memoriais, mas também as apreciações dos contemporâneos, os depoimentos dos empreendedores, as observações dos usuários e até a escrituração comercial... e por fontes secundárias, temos considerado todos os textos de referência sobre o período estudado, como ensaios históricos e críticos. (KATINSKY, 2005, p. 46)

O que se pode deduzir dessa citação é que na pesquisa arquitetônica o edifício também é um documento, e que, portanto, a metodologia de enfoque arquitetônico e visual, através da coleta de imagens (desenhos e fotografias) tem uma importância fundamental neste estudo. Parte-se também do princípio que arquitetura é construção, conforme indicado por Costa (1995), quando escreveu que a: 
Arquitetura deve ser entendida como construção concebida com a intenção de ordenar e organizar plasticamente o espaço, em função de uma determinada época, de um determinado meio, de uma determinada técnica e de um determinado programa (COSTA, 1995, p. 245).

Esta compreensão de observar a época, o meio, a técnica e o programa são fundamentais. Pois, através do olhar sobre a história cultural econômica, política, social do recorte cronológico na qual foi produzido o objeto arquitetônico, pode-se ter um entendimento do processo projetual e construtivo do mesmo. Estes condicionantes certamente dialogam diretamente com o produto deste processo, a edificação, que é resultante da interlocução destas variantes.

Assim, entende-se que arquitetura é a construção do espaço, e que trabalha com diversas dimensões em seu existir, entre elas a dimensão espacial; estética; técnica; ambiental; econômica; entre outras, conforme colocaram diversos autores, entre eles, Frampton, que em 1995, propôs a tectônica, como a dimensão construtiva da arquitetura, colocando-a em um nível de igualdade com a dimensão espacial e formal, que havia sido privilegiada na modernidade.

Após os anos 60, o termo tectônica foi retomado por Kenneth Frampton em três ocasiões marcantes: 1983, 1990, 1995.

Nos dois primeiros trabalhos - "Towards a critical regionalism: Six points for an architecture of resistance" (FRAMPTON, 1983), e "Rappel à l'ordre: The case for the tectonic" (FRAMPTON, 1990) -, o autor britânico utilizou o termo como argumento crítico ao pós-moderno, apoiando-se para isso em autores alemãs do século XIX, como Botticher e Semper, que trataram do conceito em oposição ao ecletismo que dominava na produção artística e arquitetônica naquele período. No livro "Studies in tectonic culture", Frampton (1995) retomou tal discussão a partir de um enfoque não apenas de argumentação crítica, mas como uma abordagem teórica- analítica. Ele começou por uma revisão da etimologia do termo para, em seguida, analisar as tradições construtivas francesas e alemãs, e, depois, aplicar o conceito de tectônica ao estudo das obras de seis mestres da arquitetura moderna: Frank Lloyd Wright, Auguste Perret, Mies van der Rohe, Louis Kahn, Jorn Utzon e Carlo Scarpa. Através da análise das obras de arquitetos modernos, o autor observou a importância em se privilegiar o potencial expressivo estrutural, dos materiais e técnicas construtivas, defendendo a tectônica como "a poética da construção", que enfoca o envoltório do espaço arquitetural em sua dimensão material e tátil, com ênfase para os nexos entre expressividade arquitetônica e materialidade. O trabalho teve repercussão internacional, e até hoje é considerado a mais importante obra sobre a noção de tectônica, o grande responsável pela popularização do conceito na atualidade.

Para Frampton a tectônica se refere, não unicamente à estrutura, mas à pele da construção (o envelope), e, assim, ao seu aspecto representacional, demonstrando que a construção é uma complexa montagem de elementos diversos. Assim, o uso do termo tem como premissa a existência, em arquitetura, de um juízo estético inerente ao ato construtivo, onde o fazer arquitetônico é, também, procedente da cultura técnica e das condições materiais em tempos e lugares distintos. Com base nele estuda-se a arquitetura não apenas como manifestação artística, mas também, como fenômeno tecnológico.

Outro conceito que aporta a construção desse artigo trata-se do entendimento do que vem a ser o projeto arquitetônico, entendido aqui como um processo, que aparece como ferramenta para se criar a Arquitetura. Por processo compreendem-se as formas de proceder do arquiteto, que, além de enfrentar as condições e dificuldades técnicas próprias do trabalho a ser desenvolvido, põe em jogo suas capacidades específicas de juízo e concepção. O projeto enquanto processo possui caminhos a serem seguidos, nos quais é necessária a definição de um programa a ser atendido, um lugar no qual será implantado o edifício, e um modo de construir a ser determinado.

Os condicionantes projetuais interferem diretamente na tomada de decisões, devendo ser considerado aspectos como as necessidades do cliente; as condições geográficas do lugar a ser implantada a obra (clima, vegetação, relevo, etc); os custos que poderão ser investidos na obra, interferindo na escolha dos materiais, sistemas e técnicas construtivas; entre outros.

A realização de um projeto de arquitetura, como qualquer outro trabalho, tem premissas que lhe são próprias: há um programa a ser atendido, há um lugar em que se implantará o edifício, e há um modo de construir a ser determinado. Esse conjunto de premissas é elaborado graficamente em um desenho que opera como mediador entre a concepção do projeto e sua realização concreta (MACIEL, 2003, p.1).

No livro "Teoria do Projeto" o arquiteto e professor catalão Helio Piñón (2006) formulou uma teoria, fruto de suas reflexões suscitadas pelo ensino de arquitetura e pela prática projetual, discutindo pontos como projeto/lugar/tempo, projeto/sociedade, e principalmente a questão da forma e a matéria. Segundo ele, não há projeto sem matéria, relacionando o construtivismo e a tectonicidade, material de construção e material de projeto. Assim, sobre o processo projetual o autor comenta: 
O processo do projeto consiste, na realidade, em uma série de fases sucessivas em que a passagem de uma à seguinte se apoia em um juízo estético subjetivo realizado sobre a primeira, de modo que o itinerário depende da estratégia a que os sucessivos juízos dão lugar. Tal proposta se submete à verificação tanto do programa como das condições do lugar; dessa confrontação surgem modificações da proposta que podem afetar tanto o modo de estruturar a atividade como incidência do edifício no sítio (PIÑÓN, 2006, p. 48).

Mesmo afirmando que não é um experto em questões relacionadas ao tema patrimonial, o mestre catalão definiu o patrimônio arquitetônico como "um legado cuja preservação garantiria a consciência histórica que um conjunto social tem do âmbito espacial em que se enquadra; no limite, a capacidade do homem para ordenar o espaço construído" (PIÑÓN, 2006, p.162).

Conforme apontou Choay (2006), em seu livro "A Alegoria do patrimônio", após a Convenção realizada por uma Assembleia Geral da UNESCO em 1972, foi trazida à tona a "mundialização" dos valores e das referências ocidentais que contribuíram para a expansão ecumênica das práticas patrimoniais. $O$ texto resultante dessa convenção foi publicado somente em 1983, e contribuiu de forma fundamental para a amplitude do que poderia ser considerado patrimônio. A autora francesa observou ainda que, paralelamente a essa discussão, houve uma expansão tipológica do patrimônio histórico, inserindo aí, edificações modestas, de arquitetura vernácula, nem memoriais, nem prestigiosas, reconhecidos e valorizados por disciplinas novas como a etnologia rural e urbana, a história das técnicas, entre outros- que passaram a integrar o corpus patrimonial.

Os acervos patrimoniais vêm sendo estudados nas instituições de ensino, seja em sala de aula, seja em trabalhos de pesquisa, que demandam por metodologias analíticas dos objetos arquitetônicos que contribuam com a qualidade das investigações, e que procurem considerar o maior número possível de reflexões sobre o mesmo, observando o sistema que circundou tal obra e o tornaram ser o que é, em sua existência na construção do cenário no qual está inserido.

\section{ANÁLISE DO OBJETO ARQUITETONICO}

Após estes esclarecimentos iniciais, será exposto do que trata cada ponto desta análise arquitetônica, deixando-se registrado aqui, que muitas vezes, constata-se que as informações coletadas em distintas dimensões do objeto arquitetônico (Figura 1) podem coincidir e interagir entre si, conforme será visto, pois a interdisciplinaridade e multidisciplinaridade do conhecimento na área da arquitetura são constantes, ficando difícil muitas vezes desassociar determinadas categorias que poderão estar intrinsecamente conectadas.

Figura 1: O objeto arquitetônico e suas dimensões.

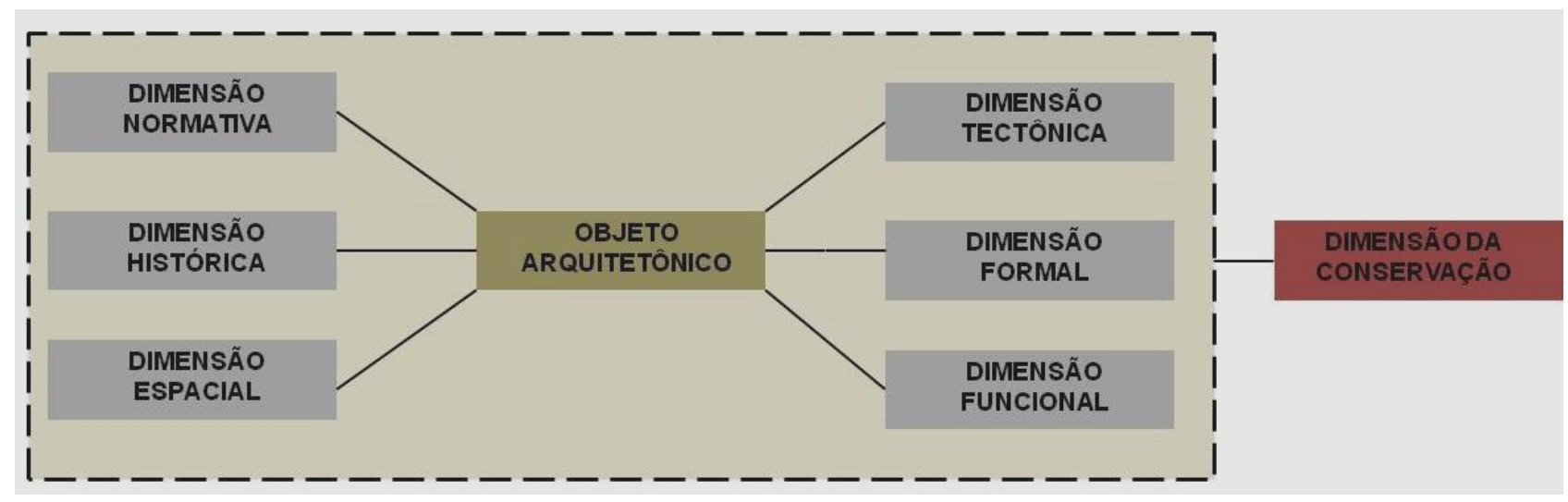

Fonte: Desenho da autora (2019).

A metodologia proposta metodológica para pesquisa arquitetônica patrimonial trabalha com sete dimensões para a análise do objeto arquitetônico, a saber: 1) Dimensão normativa; 2) Dimensão histórica; 3) Dimensão espacial (subdividida em 3.1 O espaço externo e 3.2 O espaço interno); 4) Dimensão Tectônica; 5) Dimensão Funcional; 6) Dimensão formal; 7) Dimensão da conservação do objeto.

Como esclarecimento, deixa-se claro aqui, que a dimensão da conservação é trabalhada como uma fase conclusiva, realizada após a análise de todas as demais, e para isso, apoia-se em métodos específicos expostos por autores brasileiros como Lichtenstein (1986), Tinoco (2009), e Ribeiro (2016), conforme será visto posteriormente. 


\title{
Dimensão Normativa
}

A dimensão normativa faz referência ao levantamento inicial que se deve ter sobre as leis, decretos, registrosque protegem este determinado bem. A realização de uma pesquisa em órgãos públicos relacionados à preservação cultural em nível municipal, estadual e federal, é fundamental.

Nesta análise a coleta de informações em fontes primárias e secundárias, também fornecerão pistas para a compreensão do valor/ significado deste objeto, seja do ponto de vista semântico, semiótico ou estético, conforme enfatiza Serra (2006, p.42), entendendo as causas de este objeto estar ou não, ainda devidamente protegido por leis de preservação.

Observa-se que patrimônio cultural sofre grandes dificuldades em sua preservação no nosso país. A Constituição Federal de 1988, em seu artigo 216 determinou que constituíssem patrimônio cultural brasileiro, os bens de natureza material e imaterial, tomados individualmente ou em conjunto. No $\S 1^{\circ}$ desse artigo, determinou que o Poder Público, com a colaboração da comunidade, promoverá e protegerá o patrimônio cultural brasileiro, por meio de inventários, registros, vigilância, tombamento e desapropriação, e de outras formas de acautelamento e preservação.

O Instituto de Patrimônio Histórico e Artístico Nacional (IPHAN) é o responsável pela preservação do Patrimônio Cultural Brasileiro em nível federal, ficando os Estados e Municípios com os encargos locais.

Segundo Moreira (2013, p.118), "o inventário serve para individualização de bens culturais e juntada de informações técnicas de natureza histórica, artística, sociológica, antropológica, dentre outras, que possibilitem embasamento às ações protetivas de competência do poder público". E a realização de análises arquitetônicas acadêmicas tem colaborado com a alimentação de inventários do acervo patrimonial, principalmente daqueles acervos mais recentes, como o patrimônio moderno, industrial e modesto.

O resultado do trabalho de inventário possibilita a realização do registro de determinado bem junto ao órgão do poder público competente, recaindo sobre esse, as disposições protetivas decorrentes do reconhecimento do patrimônio cultural.

O "registro", tal como concebido na Constituição do Brasil (1988) é antes de tudo uma forma de reconhecimento e busca da valorização dos bens de natureza material e imaterial. É fundamental compreender o que vem a ser o conceito de "registro", do ponto de vista jurídico, de acordo com Silva (2004), na obra Vocabulário Jurídico:

\begin{abstract}
"REGISTRO". Do latim regestra, plural neutro de regestus (copiado, traslado), entende-se o assento ou cópia, em livro próprio, de ato que se tenha praticado, ou documento que se tenha passado. "Em sentido amplo, registro na acepção jurídica, entende-se a soma de formalidades legais, de natureza extrínseca, a que estão sujeitos certos atos jurídicos, a fim de que se tornem públicos e autênticos e possam valer contra terceiros. [...] Em sentido estrito, registro, entende-se a inscrição ou a transcrição do documento, em que se instrumenta o ato, em livros públicos, mantidos pelos ofícios de registros ou pelos departamentos e repartições públicas, a que se cometem semelhantes encargos ou funções. Os registros são obrigatórios ou facultativos. Quando obrigatórios, o ato jurídico somente exerce sua eficácia depois de cumprida a formalidade. Como facultativa é medida de segurança do próprio interessado, para perpetuação e autenticação do ato praticado. O processo de registro é regulado por leis próprias, havendo normas inerentes a cada espécie (SILVA, 2004, p.1184).
\end{abstract}

O reconhecimento é parte essencial da conservação do patrimônio cultural, principalmente nos tempos atuais, onde se observa o grande risco de desaparecimento desses bens culturais pela simples ausência de "registro" e consequentemente reconhecimento. Os trabalhos de pesquisa acadêmicos colaboram com tal necessidade, fazendo com que os alunos aprendam a necessidade de dialogar a produção arquitetônica histórica com o Direito, as normas, leis.

A Constituição Brasileira ao inovar ampliando o conceito de patrimônio cultural e nas ferramentas de proteção desse patrimônio objetivou a modernização de conceitos e instrumentos protetivos, contudo, ainda é patente a intenção do poder público em utilizar a ferramenta "tombamento" para patrimônio material e a Ferramenta "registro" para patrimônio imaterial, de maneira estanque e estática.

Procurar observar se este determinando bem está devidamente inventariado, registrado, tombado, inserido em alguma área de proteção ambiental torna-se um dos primeiros passos para a análise do bem arquitetônico, seja para uma análise da obra, seja para um projeto de intervenção no mesmo.

\section{Dimensão Histórica}

A dimensão histórica (Figura 2) está relacionada ao fator tempo, recorte temporal, corte cronológico ou contexto social, econômico, cultural no qual o objeto arquitetônico foi projetado e construído. Assim, deve ser realizada a análise dos fatores que originaram o projeto, a obra, o cliente, os custos, na época em estudo, 
entendendo-se que a compreensão da relação da arquitetura com a história é fundamental nesta dimensão e Berman (1954) de forma brilhante escreveu:

A arquitetura é uma arte que a nosso juízo, traduz a organização dos recursos sociais que a encomenda, reparte em termos de custos pela sociedade. Por isso mesmo, e graças ao grau de saber invertido, seu resultado final acaba transcendendo ao governante que a solicitou. Por outro lado, é também revestida de um caráter socializante, porque contém todo o esforço de uma sociedade historicamente localizada (BERMAN, 1954, p.31).

O autor complementa tal pensamento refletindo sobre a relação da arquitetura com o poder:

O governante constrói o que lhe parece ser o reflexo de sua grandeza e que lhe propaga o poder. $\mathrm{Na}$ verdade, a obra é uma projeção espacial de uma sociedade e de suas contradições, encarada plasticamente numa obra que aparentemente deveria refletir uma personalidade e um sistema de representação política (BERMAN, 1954, p.31).

Figura 2: A dimensão histórica e suas interfaces.

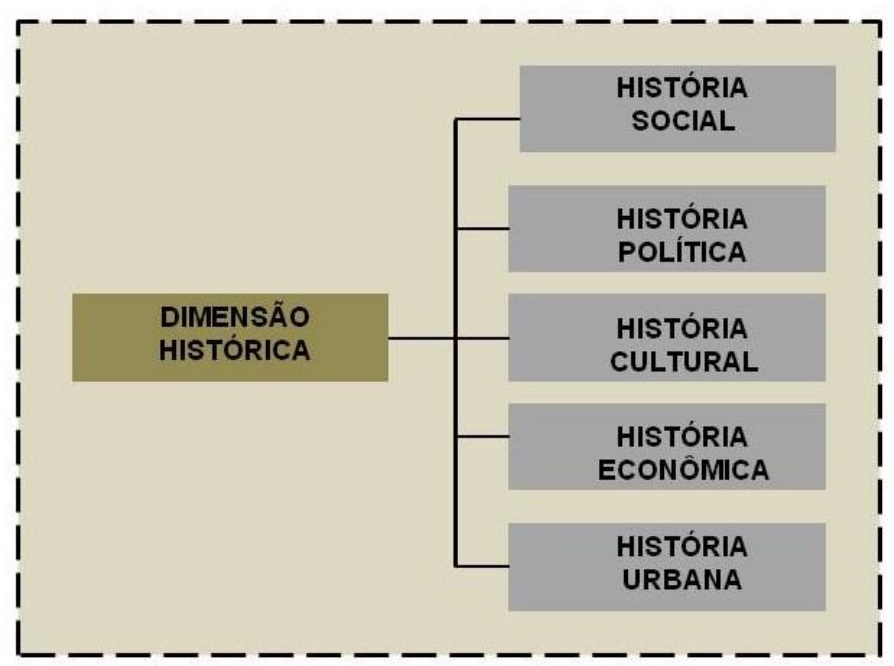

Fonte: Desenho da autora com base em Berman (1954)

Esta dimensão histórica apoia-se em Serra (2006) que, em seu livro "Pesquisa em Arquitetura e urbanismo/ Guia prático para o trabalho de pesquisadores em pós-graduação" aponta para a existência do processo que envolve o objeto e o sistema/ condicionantes que envolvem este processo. O autor entende por processo, "o modo como se sucedem os estados diferentes do sistema no tempo" (Idem, p.72), e por sistemas, "um conjunto de objetos entendidos como uma totalidade de eventos, pessoas ou ideias que interagem uns com os outros" (Ibidem, p.70). O esquema proposto pelo autor pode ser compreendido no esquema da Figura 3.

Figura 3: Esquema da metodologia de pesquisa proposta por Serra (2006).

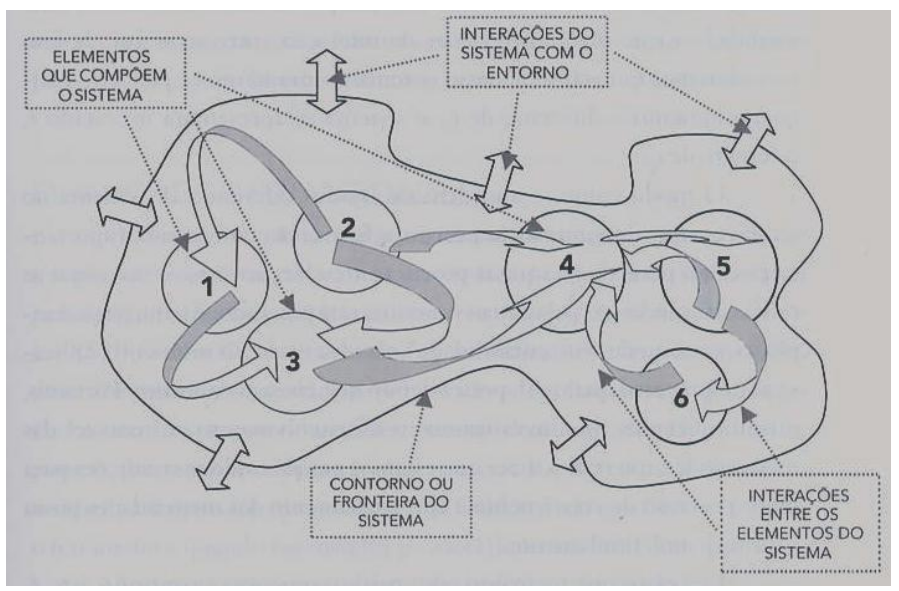

Fonte: SERRA (2006, p.70).

Estes são representados por seu contorno, por uma definição ou pela enumeração dos elementos que o compõem, como também pelas interações entre eles e entre o sistema e seu entorno. Os aspectos sociais, políticos, culturais, econômicos, são compreendidos como caminhos que se cruzam e giram em torno do processo que ocorreu e que resultou no cenário que foi construído e consolidado. 
Vale a pensa ressaltar, que além do trabalho com ferramentas da pesquisa histórica, utilizando-se fontes primárias e secundárias, em visitas a arquivos públicos, privados, bibliotecas; trabalham-se também com ferramentas da história oral, entrevistando atores envolvidos no processo projetual, construtivo e de uso da obra analisada, a fim de se levantar informações inéditas e que colaborará para a compreensão de construção a história da edificação. A coleta de depoimentos orais, através de entrevistas e diálogos mantidos com estes atores que narram a sua trajetória, suas histórias de vida e trabalho, produz assim, um rico material analítico.

Em uma de suas obras, o professor Dr. Antônio Torres Montenegro da UFPE, especialista em história oral, ressalta que o encontro com o entrevistado é sempre uma interrogação, como diante de um documento desconhecido. Assim, se observa que:

Inúmeras vezes, o entrevistado, apesar de ter vivido uma série de experiências, participado ativamente de diversos acontecimentos marcantes no período em foco, tem uma narrativa que em nada ou muito pouco ajuda na reconstrução do passado. Nesse sentido, o entrevistador tem uma parcela de responsabilidade no encaminhamento da entrevista, a capacidade de narrar, de descrever, de contar, de analisar nem sempre se encontra em todos os entrevistados (MONTENEGRO, 1994, p.21).

Alberti (2010, p. 46) também enfatiza as inúmeras possibilidades que uma entrevista pode apresentar, pois, segundo ela, "não há dúvida de que a história oral permite o registro de uma quantidade diversificada de narrativas de experiência de vida, viabilizando o acesso a visões de mundo e a história de vida proveniente de diferentes grupos sociais". Contudo, é preciso uma consciência que, como qualquer outro, a entrevista é um documento limitado, que deve ser interpretado e questionado para não assumir o papel de 'verdade absoluta'. Sobre isso, Camargo (1999) afirma que:

As interpretações que se pode dar sobre o passado, às vezes até se baseiam em trocas de datas, imprecisão nas coisas, pode haver erros, mas nós ali definimos que o que nos interessa não é a entrevista como documento absoluto (CAMARGO, 1999, p. 172).

Sobre o uso do método da história oral, Portelli (2010) apresenta a história como uma narração dialógica que tem o passado como assunto e que brota do encontro de um sujeito que ele chama de narrador; e de outro sujeito que ele chama de pesquisador. No entanto, ressalta que o que torna realmente significativa a história oral é o esforço de estabelecer um diálogo entre e para além das diferenças.

\section{Dimensão Espacial}

Parte-se do princípio que o espaço pode ser compreendido como a paisagem do ambiente natural e a paisagem do ambiente construído e, portanto, a análise da dimensão espacial ocorrerá em dois níveis: 1) o espaço externo à obra; 2) o espaço interno da edificação (Figura 4).

Figura 4: A dimensão espacial e seus níveis de análise

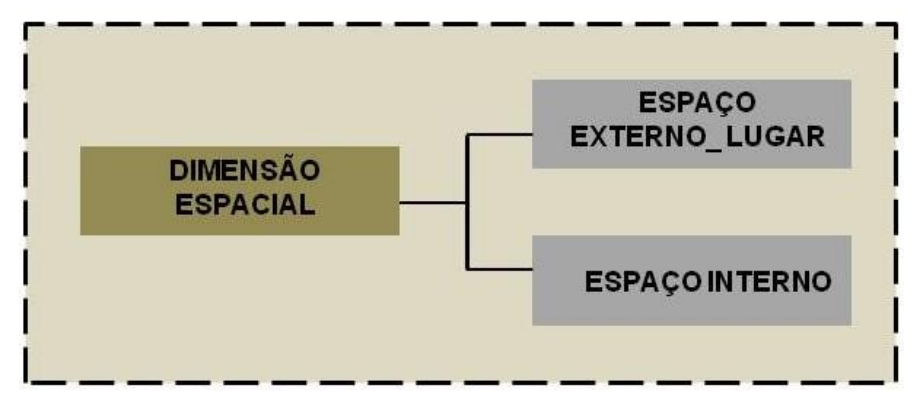

Fonte: Desenho da autora (2019)

1) No espaço externo à obra: observando-se as características do lugar e do entorno, o tipo de relevo, a hidrografia, a vegetação, a geologia, o clima, os acessos e materiais existentes nesta paisagem. Esta leitura da paisagem e seus elementos que a compõem, observando-se a identidade do lugar e suas interpretações é primordial nesta análise. Mahfuz (2004) escreveu sobre a importância do lugar para a arquitetura, colocando que se, por um lado, a arquitetura é sempre construída em um lugar, por outro lado, ela constrói esse lugar, isto é, modifica a situação existente em maior ou menor grau:

A relação com o lugar é fundamental para a arquitetura; nenhum projeto de qualidade pode ser indiferente ao seu entorno. Projetar é estabelecer relações entre partes de um todo; isso vale tanto para as relações internas a um projeto quanto para as que cada edifício estabelece com seu entorno, do qual é uma parte (MAHFUZ, 2004, s/p)

Nesta análise da dimensão espacial externa da paisagem, torna-se fundamental a leitura de uma bibliografia complementar apoiada em Lamas (2000) que realiza de forma esclarecedora estudos 
sobre a morfologia urbana e a paisagem da cidade; em Lynch (1997), que trata da imagem da cidade e seus e elementos compositivos, como por exemplo, as edificações, suas relações com o entorno, e transformações; em Cullen (1996) que trata a temática da construção e análise da paisagem urbana de maneira bastante elucidativa.

2) O segundo nível da análise da dimensão espacial tratará do espaço interno da edificação: observando-se pontos tais como as soluções de implantação da obra no terreno; a solução do programa de necessidades em planta baixa, o zoneamento, a relação entre zonas, fluxogramas, as alturas dos espaços, as relações de transparência e permeabilidade, a existência de pátios, jardins, varandas, etc. Aqui é gerado um rico material gráfico, composto por redesenhos, imagens tridimensionais, entre outros.

Esta análise espacial da obra apoia-se em metodologia proposta por Gaston e Rovira (2007) que elaboraram um guia básico de investigação sobre o projeto de arquitetura cujo objetivo é facilitar a análise crítica e arquitetônica dos objetos estudados, apresentando ferramentas para operar o material documental de maneira eficiente, assim como, ilustrar o modo mais adequado de elaborar e apresentar as conclusões. Os autores do grupo de pesquisa FORM/ UPC/ Universidade Politécnica da Catalunha, propõem o estudo gráfico projetual, realizando imagens fotográficas da obra, levantamento de material de projeto, como plantas, cortes, fachadas e construções tridimensionais, que permitem a melhor compreensão do objeto em estudo. Partem do princípio de que "investigar é sinônimo de perguntar, examinar e observar", sendo um trabalho que tem conotações científicas, estando relacionado com precisão, rigor, conotações, constatações.

Dessa maneira, o método proposto pelas professoras visa com que o aluno pesquisador se coloque no lugar do arquiteto para refazer o processo de concepção da obra, descobrindo o que há condensado em cada decisão, esclarecendo o argumento interno que lhe dá coesão.

En definitiva, adquirir una comprensión activa de la historia para avivar los mejores proyectos de la cultura moderna. Acreditar la continuidad de los valores estéticos vigentes y que se pueden alumbrar la práctica de la arquitectura al restablecerlos efectivamente en relación con las posibilidades técnicas y productivas actuales. (GASTÓN, ROVIRA, 2007, p. 34).

Assim, o enfoque da análise da dimensão espacial interna é arquitetônico e visual, e a imagem possui uma grande força, pois são os desenhos, esboços, croquis, as pranchas do projeto arquitetônico, adicionados às fotografias da edificação, que passam uma visão total do edifício analisado.

\section{Dimensão Tectônica}

A compreensão do que vem a ser tectônica - frequentemente definida como "arte da construção" (FRAMPTON, 1995) -, é fundamental para o entendimento desta dimensão. O termo "tectônica" é definido como o caráter essencial da arquitetura, através do qual parte de sua expressividade intrínseca é inseparável da maneira precisa da construção, não mais se apresentando como um manifesto contra o cenográfico e o representacional, como ocorreu nos primeiros textos de Frampton (1985 e 1990) sobre o tema, nos quais criticava a produção pós moderna como uma maneira de abordar a arquitetura enquanto concepção e construção, enquanto realização, conjuntamente. Sua compreensão mudou em relação ao original grego, principalmente devido às contribuições dos teóricos alemães Carl Bötticher e Gottfried Semper no século XIX, e, mais recentemente, devido à notável contribuição de Frampton (1995) que provocou uma renovação do debate sobre a tectônica, promovendo a noção ao estatuto de "potencial de expressão construtiva" da arquitetura, capaz de reunir aspectos materiais e construtivos aos aspectos culturais e estéticos.

Dessa forma, ao se considerar a dimensão construtiva (a tectônica) como um aspecto fundamental no valor da obra, além das dimensões espacial, formal, funcional, observa-se a necessidade de se analisar o comportamento dos elementos estruturais dos edifícios a serem preservados e devidamente conservados. Mahfuz (2004) escreveu que a importância da construção para a arquitetura é tanta que se poderia afirmar que não há concepção sem consciência construtiva:

A construção é um instrumento fundamental para conceber, não apenas uma técnica para resolver problemas. É essa consciência que separa a verdadeira arquitetura da pura geometria e das tendências que preferem abstrair a realidade física dos artefatos que projetam (MAHFUZ, 2004, s/p).

$\mathrm{Na}$ análise da tectônica, propõe-se uma pauta de pontos a serem seguidos, baseados em Gaston e Rovira (2007), tais como, observações sobre a estrutura de suporte, as soluções construtivas de peles/paredes, cobertura, detalhes construtivos e revestimentos/texturas. Entende-se aqui que um sistema construtivo é composto não apenas da estrutura da obra em si, com sua divisão básica em subestrutura (fundações), e superestrutura (pilares, vigas, e peles), mas também, de seus detalhes, junções que envolvem as relações 
entre a materialidade e as soluções projetuais, que formam o arcabouço construtivo de determinada edificação e Ihe conferem um valor construtivo a ser preservado. Conforme mostra a Figura 5, os pontos de análise da dimensão tectônica a serem considerados são:

1. Estrutura de suporte- Deve ser observado o sistema estrutural adotado; o uso de modulação, tramas ordenadoras; os materiais utilizados na superestrutura (pilares e vigas) de paredes: a) tipo de estrutura: paredes estruturais, concreto armado, perfis metálicos; b) analisar se a solução estrutural se manifesta de forma sistemática ou sintomática; c) e a relação estrutura / configuração do edifício.

2. Peles- Observar quais foram os materiais e soluções empregados nas peles (esquadrias, cobogós, pedras, etc), observando-se: a) Tipo de parede: muros, painéis de vidro; b) Relação fechamento/ estrutura; c) Fechamento sistemático ou soluções particulares; d) Sistema construtivo: economia de meios ou diversificação de soluções.

3. Cobertura: Observar quais foram os materiais e soluções construtivas utilizados na cobertura; As soluções são expressas ou implícitas? b) Qual o papel da cobertura na configuração edifício? c) Quais foram os fechamentos visuais e que soluções foram empregadas na proteção climática?

4. Detalhes construtivos existentes na obra: presentes em marquises, escadas, rampas, balcões, fachadas, coberturas, esquadrias, entre outros elementos.

5. Revestimentos e texturas plasticidade e cromatismo material: a) textura e cor de materiais; b) textura e plasticidade de soluções.

Figura 5: Pontos de análise da dimensão tectônica.

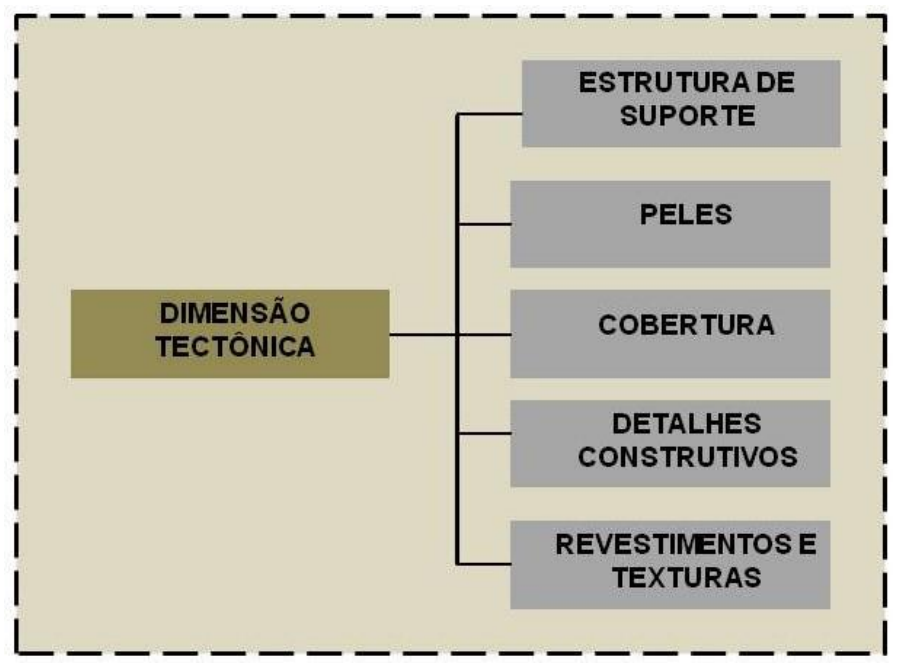

Fonte: Desenho da autora com base em GASTON e ROVIRA (2007).

\section{Dimensão formal}

Montaner (2002, p.10) escreveu que "as formas sempre compartilham valores éticos, remetem a marcos cultural, compartilham critérios sociais e se referem a significados".

A dimensão formal a ser analisada, conceitua forma, apoiando-se aqui na definição de Montaner (2002, p.8) que explica que esta deve ser entendida como estrutura essencial e interna, como construção do espaço e da matéria: "Dentro desta concepção, forma e conteúdo tendem a coincidir. O termo 'estrutura' seria a ponte que interligaria os diversos significados da forma". As obras devem ser analisadas, não apenas por sua aparência, mas também por seu conteúdo.

Por sua vez, Mahfuz (2004) escreveu que em toda construção deve-se levar em conta sua solidez, sua utilidade e sua beleza, conforme colocou Vitruvio, 2000 anos atrás, explicando que até meados do século XVIII a boa arquitetura seria aquela que apresentasse um equilíbrio entre os três componentes da tríade vitruviana: Firmitas (solidez) e Utilitas (adequação funcional), que fazem parte da esfera racional do conhecimento e Venustas (beleza, no entendimento de alguns), "que é o componente estético da tríade significando o que, em tempos pré-modernos, estava centrado nas relações proporcionais e na aplicação das ordens clássicas ao exterior dos edifícios" (MAHFUZ, 2004, s/p). O autor propôs uma atualização dessas interpretações, denominando de "forma pertinente", explicitando que: 
Pode-se tentar uma redefinição dos aspectos essenciais da arquitetura por meio de um quaterno composto por três condições internas ao problema projetual (programa, lugar e construção) e uma condição externa, o repertório de estruturas formais que fornece os meios de sintetizar na forma as outras três (MAHFUZ, 2004, s/p).

Enquanto a busca da beleza estava no centro das preocupações arquitetônicas até recentemente, o quaterno contemporâneo proposto por Mahfuz tem como foco a forma pertinente (Figura 6), resultante da interseção ou diálogo entre estes elementos: programa, lugar, construção e estruturas formais.

Figura 6: Redesenho do esquema da forma pertinente.

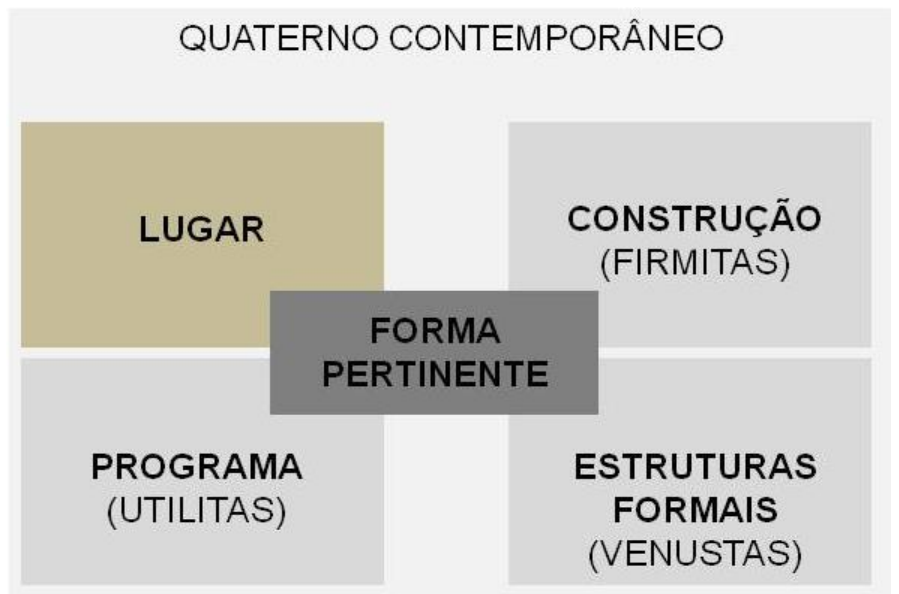

Fonte: Redesenho da autora com base em MAHFUZ (2004).

O autor salienta que a "resolução de um programa em termos formais é a essência da arquitetura. O programa é o maior vínculo que um projeto mantém com a realidade", complementando ainda, que a relação com o lugar é fundamental para a arquitetura, pois nenhum projeto de qualidade pode ser indiferente ao seu entorno: "Assim como não há relação direta entre programa e forma, as relações entre lugar e forma também dependem da interpretação do sujeito que projeta" (MAHFUZ, 2004, s/p). Sobre a construção, comenta que sua importância para a arquitetura "é tanta que se poderia afirmar que não há concepção sem consciência construtiva" (Idem). E, finalmente, sobre o papel da estrutura resistente, afirma que "uma das características das melhores arquiteturas que conhecemos é o papel importante que a estrutura resistente desempenha na definição da sua estrutura espacial e da configuração dos espaços individuais" (Ibidem).

Como as ideias de Mahfuz coincidem com as de Montaner (2004, p.10), nos apoiamos nestes autores para a análise da dimensão formal do objeto arquitetônico, pois concordamos com o segundo no sentido de considerar que a centralidade do conceito de forma permitirá o acesso a cada um dos fatores determinantes: a cada opção formal correspondem opções relacionadas às materialidades empregadas, à relevância funcional e do social, e à relação com o entorno.

\section{Dimensão funcional}

A análise da dimensão funcional ou de utilização da obra observa o uso original, as transformações sofridas referentes ao uso ao longo dos anos, e o uso atual da edificação. A funcionalidade do edifício deve ser analisada considerando-se as soluções do programa em planta, o zoneamento e por isso, é constante o diálogo com a análise da dimensão espacial interna, conforme foi visto anteriormente.

Segundo Colin (2000, p.41) o edifício possui três categorias de funções (Figura 7): função sintática, pragmática e semântica.

- A função sintática refere-se à relação do edifício com a cidade, o terreno, o lugar no qual está implantado, com seu contexto imediato. Qual o papel da edificação na paisagem na qual ela está inserida? A análise da dimensão espacial externa dialoga diretamente com esta análise da função sintática, pois os elementos que compõem este lugar, de certa forma, reforçam a importância da obra no local onde está inserida.

- A função pragmática analisa as relações da obra com seus usos, atividades. Em seus diversos momentos, desde a sua origem, à contemporaneidade, observando-se as transformações sofridas ao longo dos anos.

- A função semântica procura analisar o significado da obra para a sociedade, pois conforme coloca Colin (2000), a edificação além de abrigar uma atividade, possuir um determinado uso, também representa e significa algo para as pessoas daquele lugar. Segundo a Carta de Burra (1980), "o termo significação 
cultural designará o valor estético, histórico, científico ou social de um bem para as gerações passadas, presentes e futuras".

Figura 7: As três categorias de funções: função sintática, pragmática e semântica segundo COLLIN (2000).

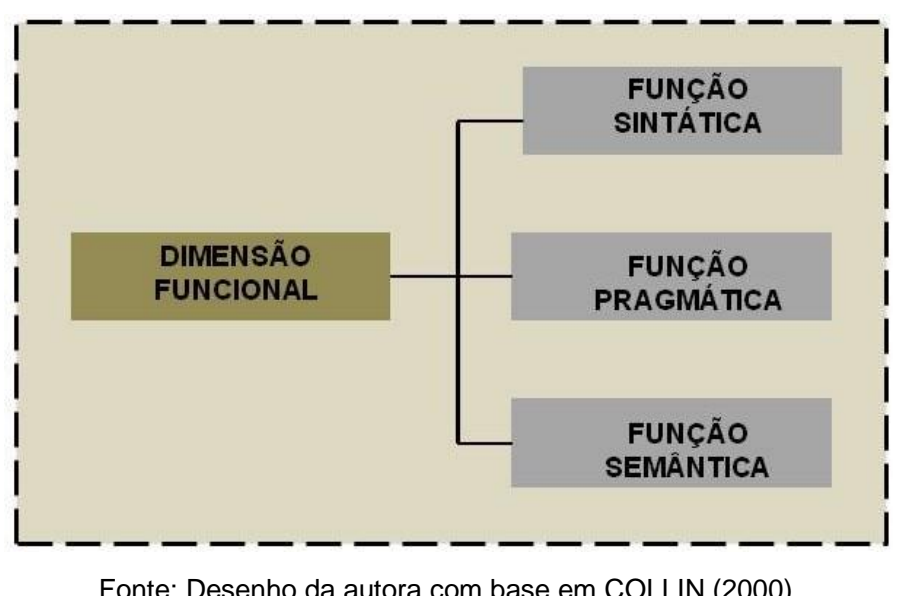

É, portanto, importante relacionar estas categorias na mesma análise, considerando-se a procura do equilíbrio entre os sistemas e deixando de lado certo radicalismo funcionalista-pragmático, o que torna 0 trabalho analítico mais contemporâneo, menos engessado. Busca-se, assim, propiciar a interação entre forma, função, espaço e tectônica, e, principalmente, enfatizar a relação da obra com a função que esta desempenha no lugar, seu significado na paisagem, e em si mesmo, com seu uso pré-estabelecido em projeto.

\section{Dimensão da conservação do objeto}

Conforme foi mostrado inicialmente, esta dimensão, que na figura 1 está colocada fora da delimitação das outras dimensões, apresenta-se como uma fase conclusiva das análises do objeto em estudo, e procura analisar o estado de conservação do mesmo, observando aspectos relevantes apontados por metodologias específicas da área da preservação patrimonial.

Külh (2009) explica que a palavra preservação, no Brasil, assim como na França, possui um sentido lato e pode abarcar uma grande variedade de ações como inventários, registros, leis de tombamento, educação patrimonial e intervenções nos bens para que sejam transmitidos da melhor maneira possível ao futuro.

Importante deixar claro que esta proposta não se aprofunda especificamente à dimensão da conservaçãouma área complexa, que vem sendo trabalhada por teóricos clássicos como Carbonara (1997), Brandi (2004), Muñoz Viñas (2005), entre tantos outros autores fundamentais que tratam da teoria do restauro e da conservação.

Sabe-se que o projeto arquitetônico de restauro vem a ser uma unidade conceitual e metodológica, e que existem princípios gerais (algo diverso de regras fixas) comuns ao campo, podendo haver variações quanto à aplicação desses princípios, os meios postos em prática, em função da realidade de cada obra ou conjunto de obras, de sua constituição física, de sua configuração e inserção num dado ambiente, de seu particular transcurso ao longo do tempo.

De acordo com a Carta de Veneza (1964), as intervenções em si assumem denominações variadas, podendo ser caracterizada como manutenção, conservação e restauro, com graus crescentes de ingerência sobre o bem. Segundo a Carta de Burra (1980), o termo conservação, "designará os cuidados a serem dispensados a um bem para preserva-lhe as características que apresentem uma significação cultural".

\footnotetext{
De acordo com as circunstâncias, a conservação implicará ou não a preservação ou a restauração, além da manutenção; ela poderá, igualmente, compreender obras mínimas de reconstrução ou adaptação que atendam às necessidades e exigências práticas. (CARTA DE BURRA, 1980, p.1).
}

Dessa maneira, serão observados nesta dimensão, os cuidados que foram (são e poderão ser) dispensados ao objeto investigado. Tais cuidados podem ser referentes a dois aspectos (Figura 8): 1) de ordem protetiva legal, e que se relaciona diretamente com a análise normativa; 2) de ordem física, que analisará a conservação da "substância" (CARTA DE BURRA, 1980), "o conjunto de materiais que fisicamente constituem o bem". 
Figura 8: A dimensão da conservação e seus aspectos.

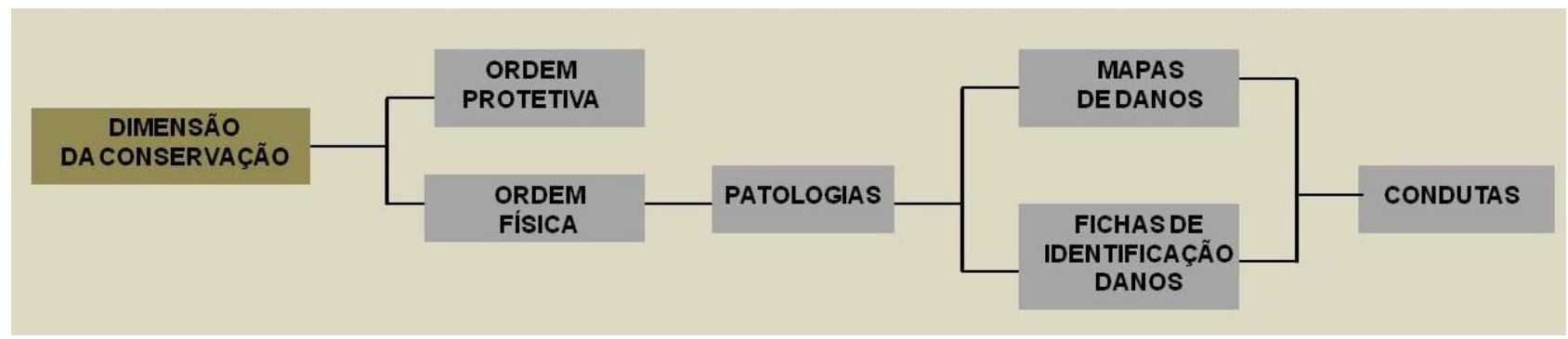

Fonte: Desenho da autora com base na Carta de Burra (1980).

A conservação baseada no respeito à substância da obra, deve por isso, analisar atentamente as suas características tectônicas. Recorda-se que tal substância que foi analisada na dimensão tectônica, será aqui, observada sob o ponto de vista de suas patologias construtivas, acarretadas pelo seu uso e processo construtivo.

O artigo $2^{\circ}$ da Carta de Veneza $(1964$, p.2) indica que "a conservação e a restauração dos monumentos constituem uma disciplina que reclama a colaboração de todas as ciências e técnicas que possam contribuir para o estudo e a salvaguarda do patrimônio monumental", por isso, a necessidade de um diálogo com outras áreas correlatas, como por exemplo, a engenharia civil, que vem tratando de problemas patológicos.

Souza e Ripper (1998) conceituaram patologia das construções como o campo da engenharia civil que se ocupa do estudo das origens, formas de manifestação, consequências e mecanismos de ocorrências das falhas e dos sistemas de degradação da construção. Uma manifestação patológica acontece com a queda de desempenho precocemente (antes de se atingir o limiar de vida útil para aquele material ou componente), diante de erros no planejamento, especificação, execução e/ou mesmo uso, os quais podem ser cumulativos ou não. Para se entender as patologias construtivas, é necessário rever os conceitos de durabilidade, vida útil e desempenho, conforme estudos baseados em Lichtenstein (1986) e Tinoco (2009).

Figura 9: Metodologia proposta por LICHENSTEIN (1986)

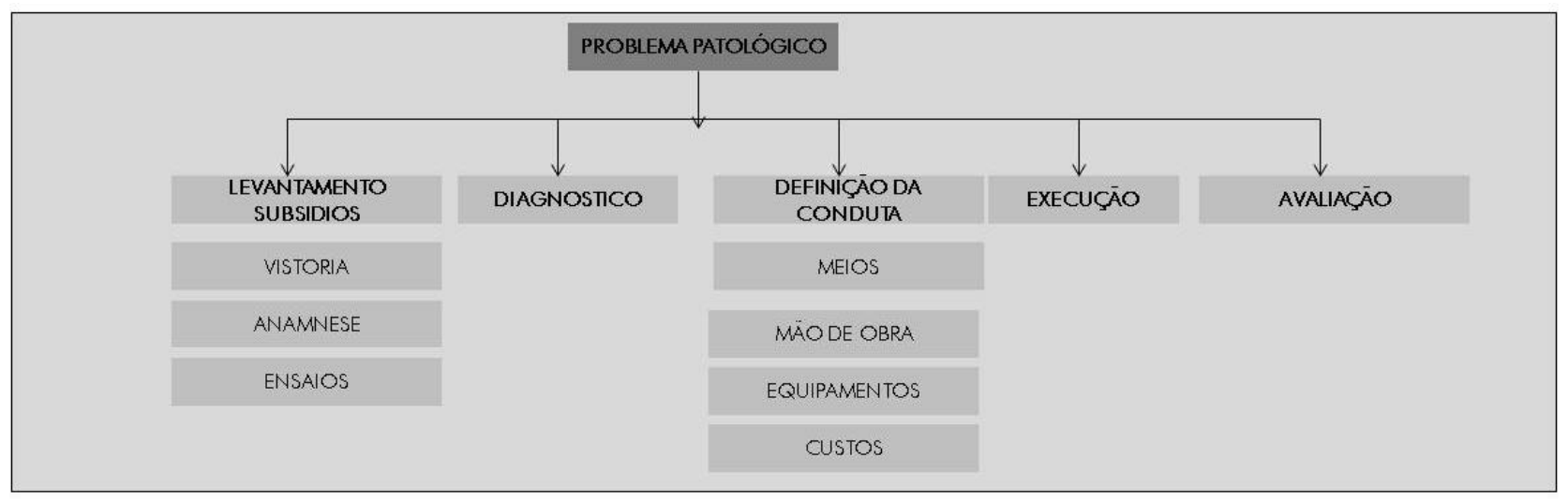

Fonte: Redesenho da autora da metodologia proposta por LICHENSTEIN (1986, p.33)

No método genérico proposto pelo professor e engenheiro civil Lichenstein (1986), o estudo dos problemas patológicos foi dividido em três fases (Figura 9):

1. Levantamento de subsídios: fase na qual são acumuladas e organizadas informações necessárias e suficientes para o entendimento completo dos fenômenos, utilizando três fontes básicas: vistoria do local; levantamento da história do problema e do edifício (anamnese do caso) e o resultado das análises e ensaios complementares.

2. Diagnóstico da situação: Entendimento dos fenômenos em termos identificados das múltiplas relações de causa e efeito que normalmente caracterizam um problema patológico. Entender os porquês e os "comos" a partir de dados conhecidos.

3. Definição de conduta: Prescrever o trabalho a ser executado para resolver o problema: definição dos meios, da mão de obra; equipamentos, previsão das consequencias. Realiza-se o prognostico, onde são levantadas hipóteses da tendência de evolução do problema e as alternativas de intervenção e seus respectivos prognósticos. 
O autor explica cada etapa e os conceitos nela envolvidos; Tinoco (2009) retomou tal método de estudo e vem desenvolvendo o mesmo em seus trabalhos práticos de conservação de edificações e na área acadêmica. $\mathrm{O}$ gráfico da Figura 10 detalha tais etapas e suas ligações, observando os fluxos e relações existentes entre as mesmas.

Figura10: Metodologia proposta por LICHESTEIN (1986)

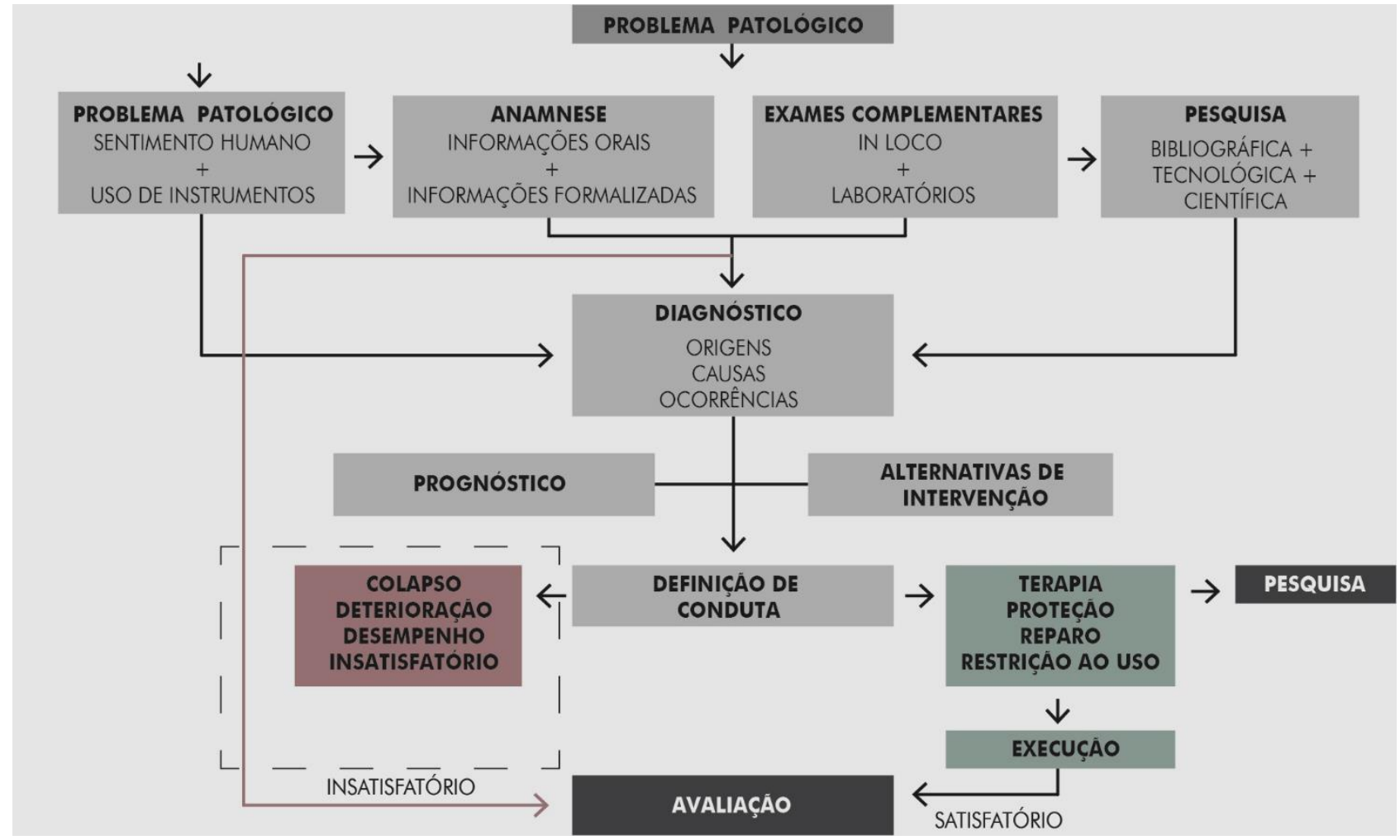

Fonte: Redesenho da metodologia proposta por LICHESTEIN (1986, p.33)

O surgimento de várias patologias ocorre em função de falhas humanas ocorridas nas quatro etapas ou fases fundamentais da vida de uma edificação. São elas: Concepção e projeto; Controle tecnológico dos materiais; Execução / construção; Uso e manutenção. Tais aspectos devem ser observados no estudo do objeto arquitetônico de interesse patrimonial, acompanhados finalmente dos mapas de danos (TINOCO, 2009), fichas de identificação de danos/ FIDs, que depois de diagnosticadas as patologias da obra analisada, indicarão a conduta que deve ser orientada para a preservação do bem.

\begin{abstract}
A preservação se impõe nos casos em que a própria substância do bem, no estado em que se encontra,oferece testemunho de uma significação cultural especifica, assim como nos casos em que há insuficiência de dados que permitam realizar a conservação sob outra forma (CARTA DE BURRA, 1980, p.3).
\end{abstract}

\title{
3 CONCLUSÃO
}

Após a observação sobre cada dimensão de análise do objeto arquitetônico, aponta-se para um dos possíveis resultados, que vem a ser o direcionamento de diretrizes de condutas a serem adotadas para a preservação da obra investigada (Figura 11). Esta prévia definição de conduta servirá de base, para um possível e futuro projeto de intervenção neste patrimônio edificado, prescrevendo o trabalho a ser executado para resolver o problema, realizando uma definição dos meios, da mão de obra; de equipamentos, de uma previsão das consequencias. 


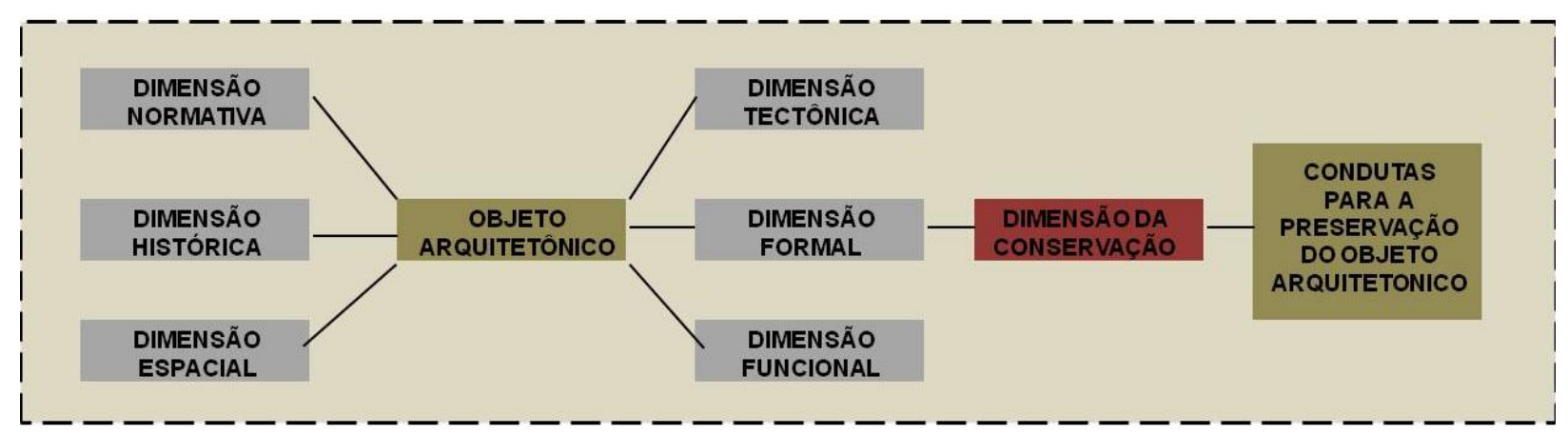

Fonte: Desenho da autora. 2019.

Este prévio prognóstico levantará hipóteses da tendência de evolução do problema e as alternativas de intervenção neste patrimônio edificado e os possíveis caminhos (Figura 12) a serem trilhados neste objeto: uma intervenção legal, ou/ e uma intervenção física (reconstrução, restauração, consolidação ou uma conservação), conforme colocou Ribeiro (2016, p.16).

Figura 12: Diagrama de intervenção no patrimônio edificado

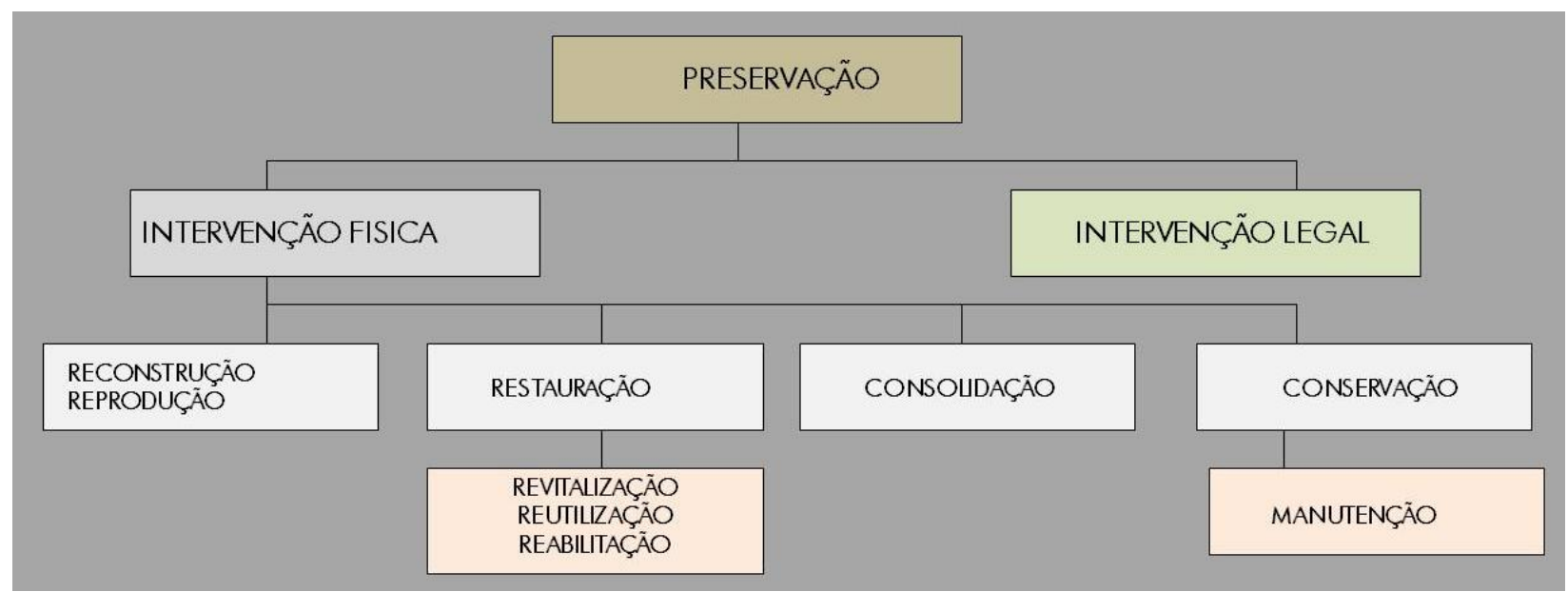

Fonte: Redesenho da autora baseada em esquema gráfico de RIBEIRO (2016, p. 16.)

Observa-se aqui que esta indicação de conduta se dá em nível incipiente, apenas como um indicativo, que deve ser devidamente aprofundado em estudos científicos patológicos realizados por profissionais especialistas. Dessa forma, conclui-se este artigo, deixando claro que ele apenas abre um caminho metodológico para o futuro arquiteto, tentando criar um roteiro analítico e crítico que colabore na compreensão do objeto arquitetônico e seus distintos condicionantes, e que se fazem presentes no provável projeto de restauro.

A professora Rossina Ribeiro da UFRJ/ Universidade Federal do Rio de Janeiro em capítulo de livro (RIBEIRO, NÓBREGA, 2016) de forma bastante didática, apresentou um diagrama de metodologia de projeto de intervenção no patrimônio edificado (Figura 13), no qual aspectos como legislação, o objeto histórico e o objeto físico são subdivididos e aprofundados em outras atividades necessárias para a compreensão e conhecimento da obra a ser trabalhada. Ao comparar a nossa proposta de análise das dimensões com a metodologia descrita nesse artigo, aos parâmetros adotados no Programa de Pós-Graduação em Arquitetura (PROARQ) e no Programa Profissional em Projeto e Patrimônio (nível de mestrado), ambos da UFRJ, observa-se que há muitos pontos comuns, o que indica estarmos no caminho certo. 
Figura 13: Diagrama de metodologia do projeto de intervenção no patrimônio edificado em etapa inicial.

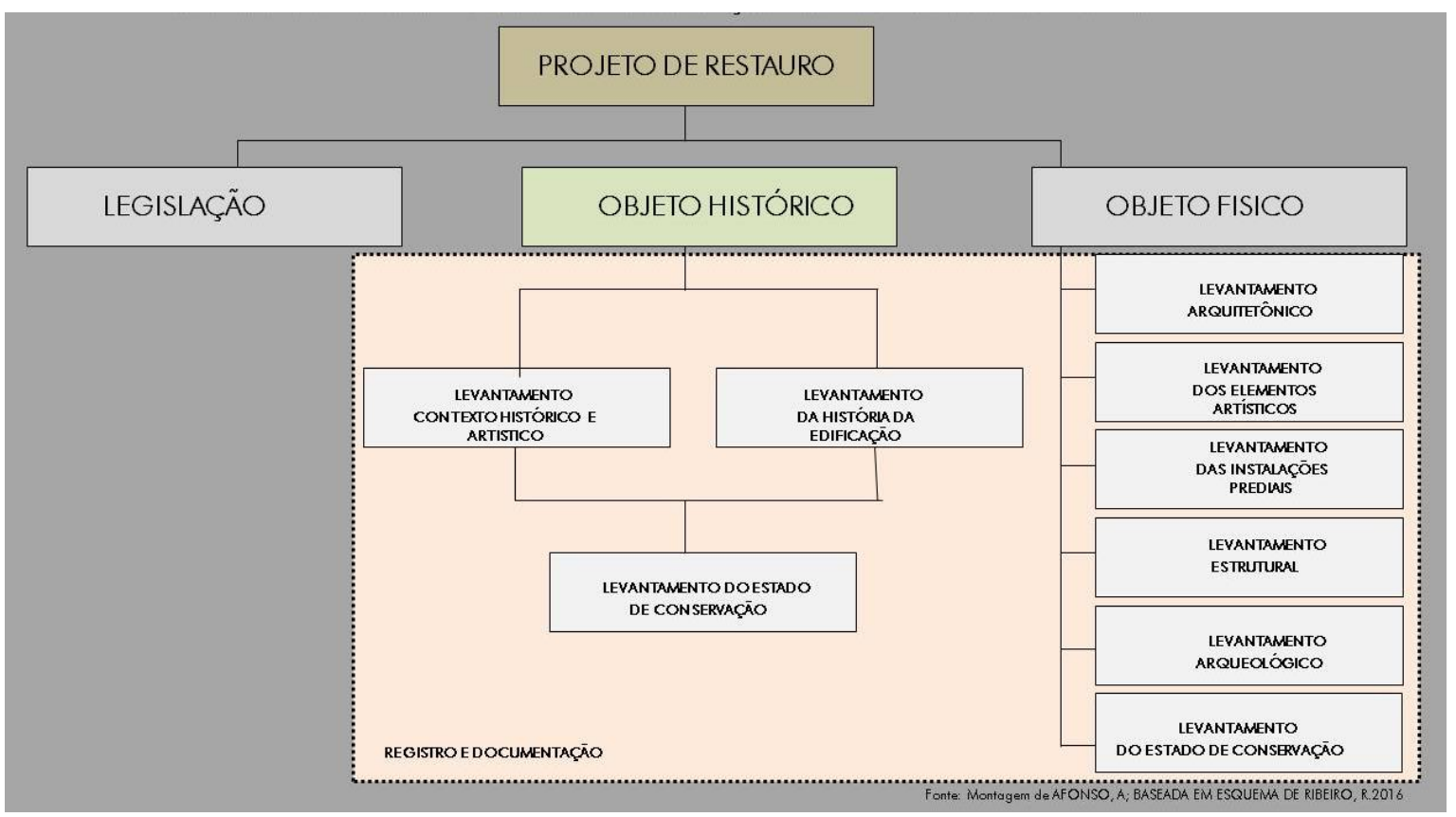

Fonte: Redesenho da autora baseada em esquema gráfico de RIBEIRO e NÓBREGA (2016, p.20).

Na proposta metodológica aqui apresentada vamos um pouco além, ao adicionar análises espaciais, tectônica, formal, funcional, sendo a análise da conservação, entendida como um quadro conclusivo das demais. Dessa maneira, recorre-se a uma reflexão realizada por Zein (2011) sobre o rigor analítico arquitetônico, propondo que o mais adequado é a realização de um estudo de reconhecimento crítico e referenciado de uma obra arquitetônica, que:

\begin{abstract}
Não poderá deixar de realizar, à medida que se aprofunda, se desdobra e se completa, um sem número de interfaces com uma ampla gama de disciplinas paralelas e conhecimento adjacentes, sem os quais seria impossível qualificar e compreender corretamente a trama de complexidade embebida no seio de qualquer obra de arquitetura (ZEIN, 2011, s/p).
\end{abstract}

O projeto de restauração necessita de uma compreensão aprofundada da obra e do ambiente construído, devendo haver esforços multidisciplinares que envolvam pesquisa histórico-documental, iconográfica, bibliográfica; estudos antropológicos, sociológicos, de viabilidade econômica; com pormenorizado levantamento métrico-arquitetônico, fotográfico, multiespectrais, laser 3D; exame de materiais e técnicas construtivas. Observando-se também, aspectos da estrutura da edificação, de suas patologias, realizando análise tipológica e formal; com um entendimento das fases por quais passou a obra; de sua configuração e problemas atuais; respeitando as várias estratificações da mesma

Finalmente, utilizando-se de instrumentos de reflexão sobre a história da arte, estética e dos vários campos disciplinares trabalhando de forma integrada, procurar empregar parâmetros para a intervenção e guiar as escolhas e decisões projetuais, objetivando respeitar e valorizar a obra em seus aspectos formais, documentais e materiais.

Tanto na área de ensino, quanto na de pesquisa e extensão, procura-se despertar no aluno/ pesquisador a necessidade de entender que o objeto arquitetônico construído com valor patrimonial perpassa por esta teia entrelaçada de conhecimentos/saberes e para sofrer qualquer tipo de intervenção, considerar as dimensões aqui expostas é fundamental. Muitos do que temos visto de más intervenções em nossas cidades, foram produzidas por profissionais que não foram devidamente capacitados nas suas formações acadêmicas para despertar para a complexidade de um projeto de intervenção no patrimônio edificado.

Kühl (2005) em seus vários textos na área de restauro chama a atenção para tratar o projeto de intervenção como um problema metodológico, antes de se tornar técnico, colocando que cada restauração deve ser analisada de modo singular, em razão das características particulares de cada obra, não obedecendo a colocações dogmáticas que baseadas em leis defasadas de órgãos preservacionistas vêm engessando soluções mais criativas e renovadoras na área. A autora ainda frisa a necessidade de aplicação constante dos princípios essenciais para intervenção no patrimônio edificado, como sejam: 1) distinguibilidade - 
considerando que a restauração não propõe tempo como reversível, não podendo induzir o observador ao engano, devendo documentar a si própria; 2) reversibilidade ou "re-trabalhabilidade" - a restauração não deve impedir, tem, antes, de facilitar qualquer intervenção futura (BRANDI, 2004, p. 48), portanto, não pode alterar a obra em sua substância - deve-se inserir com propriedade e de modo respeitoso; 3) mínima intervenção pois a restauração não pode desnaturar o documento histórico nem a obra como imagem figurada; 4) compatibilidade de técnicas e materiais, levando em conta a consistência física do objeto, atrelada ao tratamento com técnicas compatíveis, não nocivas e que possam possuir eficácia comprovada através de muitos anos.

Utilizando tal metodologia, tem-se obtido bons resultados que foram frutos de projetos de pesquisa de iniciação científica (como PIBIC e PIVIC) concluídos recentemente e que estão gerando aprofundamentos em trabalhos de conclusão de curso, desenvolvidos por Diniz (2019) no estudo das patologias de obras modernas campinenses, e Leite (2019) que se dedica ao projeto de intervenção no patrimônio industrial moderno. Tais investigações geraram artigos publicados em congressos nacionais e internacionais e se transformarão em projetos a serem mais aprofundados na pós-graduação. Garcia (2018) também adotou esta proposta metodológica em seu projeto de PIBIC 2017/2018, aprofundando-a em seu trabalho de conclusão de curso, e atualmente, no mestrado do Programa de Pós-Graduação em História da Universidade Federal de Campina Grande (UFCG), e vem trabalhando com esta linha em sua investigação sobre a conservação do patrimônio arquitetônico moderno do bairro da Prata em Campina Grande. Certamente em breve serão apresentados novos resultados, tanto no âmbito da graduação, como no da pós-graduação, além de intervenções práticas no patrimônio edificado que estejam adotando esta proposta.

A realização de estudos críticos e referenciados nos induziu a produzir este artigo, a fim de refletir mais e partir-se de um enfoque preciso, formulando-se questionamentos sobre as obras arquitetônicas, documentando e procurando caminhos viáveis para a preservação das mesmas. Procurando criar uma luz para jovens pesquisadores que se iniciam nas investigações sobre as edificações e tentando fortalecer o ativismo patrimonial, através do (re) conhecimento do patrimônio arquitetônico brasileiro. Certamente, tal proposta metodológica é passível de contínuas revisões para seu aperfeiçoamento, de modo que tem sido divulgada justamente para ser discutida, abrindo-se, portanto, para os devidos ajustes.

\section{REFERÊNCIAS}

ALBERTI, V. Ouvir contar: textos em História Oral. Rio de Janeiro: Editora FGV, 2010.

BRASIL. Constituição da República Federativa do Brasil. Texto constitucional promulgado em 5 de outubro de 1988. Com as alterações adotadas pelas Emendas Constitucionais de 01/1992 a 91/2016. Palácio do Planalto. Brasília, ago 2016. Disponível em http://www.planalto.gov.br/ccivil_03/Constituicao/Constituicao.htm. Acesso em 20/jun/2018.

BERMAN, M. Conversaciones sobre la guerra y la paz. Barcelona: Luiz Carral.1954.

BRANDI, C. Teoria da Restauração. São Paulo, Ateliê, 2004.

CAMARgO, A. Como a História Oral chegou ao Brasil. História Oral. Revista da Associação Brasileira de História Oral São Paulo, n. 2, jun.1999.

CARBONARA, G. Avvicinamento al Restauro. Napoli, Liguori, 1997.

CARTA DE BURRA. Republicada pelo Instituto do Patrimônio Histórico e Artístico Nacional (IPHAN). 1980. Disponível em http://portal.iphan.gov.br/uploads/ckfinder/arquivos/ Carta\%20de\%20Burra\%201980.pdf. Acesso em 14/jun/2019.

CARTA DE VENEZA. Republicada pelo Instituto do Patrimônio Histórico e Artístico Nacional (IPHAN). 1964. Disponível em http://portal.iphan.gov.br/uploads/ckfinder/ arquivos/Carta\%20de\%20Veneza\%201964.pdf. Acesso em 24/out/2019.

CHOAY, F. A Alegoria do Patrimônio. 4⿳亠丷. Ed. São Paulo: Estação Liberdade/UNESP, 2006.

COLIN, S. Introdução à arquitetura. Rio de Janeiro: UAPE, 2000.

COSTA, L. Considerações sobre arte contemporânea (1940). In: L. COSTA, Registro de uma vivência. São Paulo, Empresa das Artes, 1995.

CULLEN, G. Paisagem urbana. Lisboa: Edições 70, 1996.

DINIZ, D. Tectônica da modernidade: desafios para a preservação da arquitetura moderna em Campina Grande. Campina Grande: PIBIC UFCG 2018/2019, 2019.

ECO, U. Como se faz uma tese. São Paulo: Editora Perspectiva, 1989.

FELIZOLA, J. O sagrado coração da cidade: diretrizes para conduta de intervenção na catedral de Petrolina, PE. Campina Grande: Trabalho de Conclusão de Curso em Arquitetura e Urbanismo, UFCG, Julho de 2018. 
FRAMPTON, K. Towards a critical regionalism: Six points for an architecture of resistance. In: H. FOSTER (Dir.). The antiaesthetic: Essays on postmodern culture. Port Townsend (Washington): Bay Press, 1983, p. 16-30.

FRAMPTON, K. Rappel à l'Ordre: The Case for the Tectonic. Architectural Design, Londres, v. 60, n. 3-4, p. 19- 25.1990. FRAMPTON, K. Studies in tectonics culture. Cambridge. Massachussets. The MIT Press.1995.

GARCIA, M. A prata que vale ouro: patrimônio moderno da década de 60. Campina Grande: Relatório PIBIC/UFCG 2017/2018. 2018.

GASTÓN, C; ROVIRA, T. El proyecto Moderno: Pautas de Investigación. Barcelona: Ediciones UPC, 2007.

KATINSKY, J. R. Pesquisa Acadêmica na FAUUSP. São Paulo: FAUUSP. 2005.

KÜHL, B. M. Preservação do Patrimônio Arquitetônico da Industrialização. Problemas teóricos de restauro. Cotia, Ateliê / FAPESP, 2009, pp. 59-100.

História e Ética na Conservação e na Restauração de Monumentos Históricos, Revista CPC, 2005, v. $1 .$, n. 1. (www.usp/cpc/v1)

Os Restauradores e o Pensamento de Camillo Boito sobre a Restauração. In: C. BOITO. Os Restauradores. Cotia, Ateliê Editorial, 2002, pp. 9-28.

AUH 412 - Notas de Aula (Restauração hoje: projeto e criatividade), 2015. Disponível em file://E:/UFCG/PROJETO\%205/TEXTOS\%20BEATRIZ\%20KULH/Auh412_2015-notasdeaulabkuhl.pdf. Acesso em 10/ago/2019.

LAMAS, J. Morfologia Urbana e Paisagem da Cidade. Lisboa: Fergáfrica, 2000.

LEITE, J. A relação entre Concepção Arquitetônica e Estrutura em projetos Industriais Modernos em Campina Grande. Estudos de Casos. Campina Grande: PIVIC UFCG 2018/2019. 2019.

LICHTENSTEIN, N. Patologia das construções. Boletim Técnico №06/86 da Escola Politécnica da USP. SP: USP. 1986

LYNCH, K. A imagem da cidade. São Paulo: Martins Fontes, 1997.

MACIEL, C A. Arquitetura, projeto e conceito. Arquitextos, São Paulo, ano 04, n. 043.10, Vitruvius, dez. 2003 Disponível em <https://www.vitruvius.com.br/revistas/read/arquitextos/04.043/633>. Acesso em 10/set/2018.

MAHFUZ, Edson. Reflexões sobre a construção da forma pertinente. Arquitextos, São Paulo, ano 04, n. 045.02, Vitruvius, fev. 2004. Disponível em http://www.vitruvius.com.br/revistas/read/arquitextos/04.045/606. Acesso em 20/ out/2018.

MELO, C. F. A. Requalificação de um edifício histórico em Fortaleza/CE: uma proposta para promover a permanência urbana e garantir a memória da cidade. Campina Grande: Trabalho de Conclusão de Curso em Arquitetura e Urbanismo. UFCG. Julho de 2018.

MONTANER, J. As formas do século XX. Barcelona: Gustavo Gili, 2002.

MONTENEGRO, A. T. História Oral e memória. A cultura popular revisitada. 3ạ. Edição. São Paulo: Contexto, 1994.

MOREIRA, Lilian. Patrimônio cultural imaterial e sua proteção pelo ministério público. In: M. MIRANDA. Patrimônio Cultural. Belo Horizonte: Del Rey, 2013.

MUÑOZ VIÑAS, S. Teoría Contemporánea de la Restauración. Editorial Síntesis, Madri; 1ª edição, 2004.

PIÑÓN, H. Teoria do projeto. Traduzido por E. Mahfuz. Porto Alegre: Livraria do arquiteto. 2006

PORTELLI, A. Memória e diálogo: desafios da História Oral para a ideologia do século XXI. In: M. M. FERREIRA; T. M. FERNANDES; V. ALBERTI (Org.). História Oral: desafios para o século XXI. Rio de Janeiro: FIOCRUZ, 2000.

RIBEIRO, R.; NÓBREGA C. (org). Projeto e patrimônio: reflexões e aplicações. Rio de Janeiro: Rio Books, 2016.

SERRA, G. Pesquisa em arquitetura e urbanismo. Guia prático para o trabalho de pesquisadores em pós-graduação. São Paulo: EDUSP, 2006.

SILVA, D. P. Vocabulário jurídico. Rio de janeiro: Editora Forense. 2004

SOUZA, V. C.; RIPPER, T. Patologia, recuperação e reforço de estruturas de concreto. São Paulo: PINI, 1998.

TINOCO, J. E. Mapa de danos. Recomendações básicas. Recife: CECI/MDU, 2009.

VIEGAS, W. Fundamentos da metodologia científica. Brasília: Editora da UNB: Paralelo 15, 1999.

ZEIN, R. V. A década ausente. É preciso reconhecer a arquitetura brasileira dos anos 1960-70. Arquitextos, n. 076.02. São Paulo, Portal Vitruvius, set. 2006. Disponível em http://www.vitruvius.com.br/arquitextos/arq076/arq076 02.asp. Acesso em 20/out/2018.

NOTA DO EDITOR (*) O conteúdo do artigo e as imagens nele publicadas são de responsabilidade do(s) autor(es). 